DEUTSCHE LANDE / DEUTSCHE KUNST heraugegeben von Burlabro Meier 


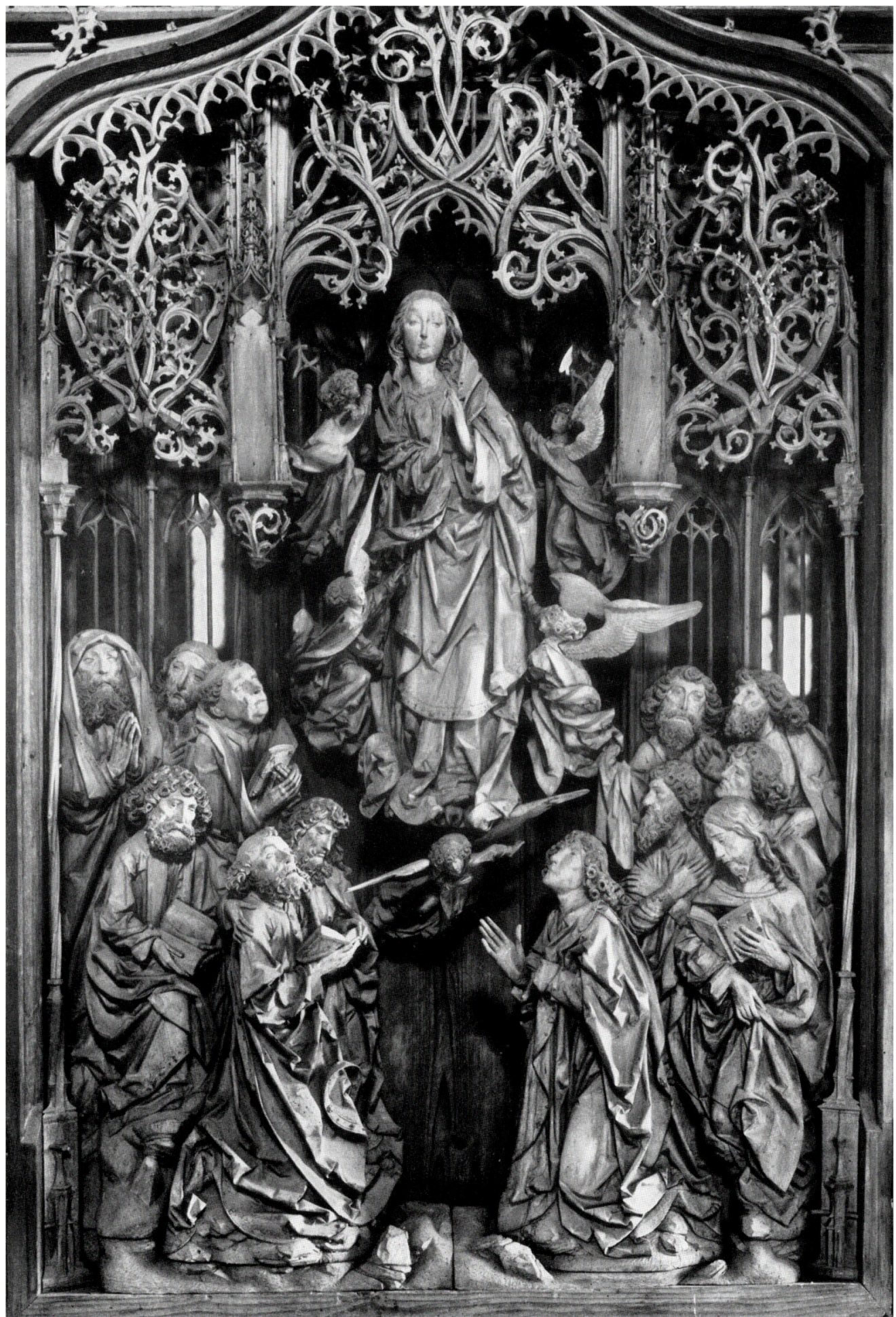

Herrgottskapelle bei Creglingen. Mittelfchrein oes Marienaltars 


\section{Die Meifterwerke}

\section{Tílman Riemenfchmeiders}

AUFGENOMMEN VON LEO GUNDERMANN BESCHRIEBEN VON THEODOR DEMMLER 
E a li ferten: Oas Papier Scheufelen, Oberlenningen; Oic Drudiftödze Bendiz \& Lemlic, Oen Druck Filgentreff \& Co, Oen Einbano Biblo, , alle in Berlin. Copyright 1936 by Deuticher Kunftoerlag, Birlin 